Research Article

\title{
Leaf Extracts of Aerva lanata Inhibit the Activities of Type 2 Diabetes-Related Enzymes and Possess Antioxidant Properties
}

\author{
Musbau Adewunmi Akanji $\mathbb{D}^{1},{ }^{1}$ Samson Olasunkanmi Olukolu $\mathbb{D}^{2}{ }^{2}$ \\ and Mutiu Idowu Kazeem iD ${ }^{2}$ \\ ${ }^{1}$ Department of Biochemistry, University of Ilorin, PMB 1515 Ilorin, Nigeria \\ ${ }^{2}$ Department of Biochemistry, Lagos State University, PMB 0001 Ojo, Lagos, Nigeria \\ Correspondence should be addressed to Musbau Adewunmi Akanji; akanjima@yahoo.com
}

Received 4 May 2018; Revised 4 August 2018; Accepted 26 August 2018; Published 26 September 2018

Academic Editor: Angel Catalá

Copyright ( $) 2018$ Musbau Adewunmi Akanji et al. This is an open access article distributed under the Creative Commons Attribution License, which permits unrestricted use, distribution, and reproduction in any medium, provided the original work is properly cited.

\begin{abstract}
The leaves of Aerva lanata are one of the indigenous medicinal plants used in the management of diabetes mellitus and its associated complications in Africa. However, its effect on the activities of diabetes-related enzymes has not been investigated. This study evaluated the in vitro inhibitory effects of different extracts of the A. lanata leaf on the activities of diabetes-related enzymes ( $\alpha$-amylase and $\alpha$-glucosidase) and chemically induced free radicals. Aqueous, ethanol, and hydroethanol extracts of $A$. lanata leaves were subjected to a standard enzyme inhibition assay followed by determination of modes of inhibition of the enzymes. The antioxidant activities of the extracts were evaluated using 1,1-diphenyl-2-picrylhydrazyl (DPPH) and 2,2-azino-bis-(3-ethylbenzothiazoline-6-sulphonic acid) (ABTS). The results obtained showed that the hydroethanol extract of the $A$. lanata leaf optimally inhibited both $\alpha$-amylase $\left(\mathrm{IC}_{50}: 2.42 \mathrm{mg} / \mathrm{mL}\right.$ ) and $\alpha$-glucosidase $\left(\mathrm{IC}_{50}: 0.23 \mathrm{mg} / \mathrm{mL}\right)$. The Lineweaver-Burk plot revealed that the mode of inhibition of both enzymes by the hydroethanol extract was uncompetitive. However, the hydroethanol and aqueous extracts displayed the best DPPH and ABTS radical-scavenging ability, respectively. It can be concluded that the A. lanata extract inhibited the activities of both $\alpha$-amylase and $\alpha$-glucosidase uncompetitively, which may be attributed to its free radical-scavenging properties and rich phenolic composition.
\end{abstract}

\section{Introduction}

Diabetes is one of the global health emergencies of the $21^{\text {st }}$ century, which affects about 425 million people worldwide, and this may rise up to 629 million by the year 2045 [1]. Type 2 diabetes is the commonest form of this disease which is characterized by insulin resistance or reduced insulin sensitivity leading to hyperglycemia [2]. Management of type 2 diabetes normally entails lifestyle modification (diet and exercise) as well as treatment with oral hypoglycemic drugs, such as insulin secretagogues (e.g., glimepiride) to stimulate insulin secretion, biguanides (e.g., metformin) to decrease hepatic glucose output, thiazolidinediones (e.g., rosiglitazone) to improve insulin sensitivity, and alpha-glucosidase inhibitors (e.g., acarbose) to reduce starch and sucrose digestion [3].

Diabetes and some other diseases like cancer and stroke have been linked to oxidative stress which arises from the excessive production of free radicals in the mitochondrial electron transport chain [4]. Though the natural defence mechanism of animals detoxifies these free radicals with the aid of antioxidant molecules and enzymes, oxidative stress occurs when the effect of free radicals outweighs that of the cellular antioxidants [5]. Therefore, searching for antioxidant and antidiabetic agents from plants is an important strategy required to mitigate the widespread nature of diabetes. This is because present synthetic drugs have many drawbacks ranging from limited efficacy to several side effects such as hypoglycemia, weight gain, and chronic tissue damage.

Aerva lanata (Linn.) Juss. Ex Schult. (Amaranthaceae) is an erect or prostrate plant found in the tropical regions of Africa, India, Arabia, and the Philippines [6]. Commonly referred to as "ewe aje" in the western part of Nigeria and "polpala" in India, the plant enjoys extensive usage in traditional medicine. Different parts of the plant have been used 
in the treatment of several diseases including inflammation, malaria, kidney stone, rheumatism, bronchitis, haemorrhage, diuresis, jaundice, and diabetes [7]. The plant is very rich in phenolic compounds and alkaloids as well as steroids. Some of the isolated compounds include kaempferol, tiliroside, $\beta$-sitosterol, aervoside, syringic acid, and canthin-6one [8]. A plethora of studies have reported the pharmacological potentials of Aerva lanata ranging from hepatoprotective, anti-inflammatory, antimicrobial, antihelminthic, and antitumour activities to antidiabetic activities [9].

Though there are reports on the hypoglycemic and antidiabetic potentials of Aerva lanata, there is no information on the inhibition of $\alpha$-amylase and $\alpha$-glucosidase by the plant. This study therefore presents inhibitory effects of the Aerva lanata extract on diabetes-related enzymes and free radical-scavenging properties of the plant.

\section{Materials and Methods}

2.1. Chemicals and Reagents. Porcine pancreatic $\alpha$-amylase, rat intestinal $\alpha$-glucosidase, 1,1-diphenyl-2-picrylhydrazyl $(\mathrm{DPPH})$, quercetin, nitroblue tetrazolium (NBT), dinitrosalicylic acid (DNS), acarbose, and para-nitrophenyl-glucopyranoside (pNPG) were products of Sigma-Aldrich Co., St. Louis, USA, while starch soluble (extra pure) was obtained from J.T. Baker Inc., Phillipsburg, USA. Other chemicals and reagents were of analytical grade, and the water used was glass-distilled.

2.2. Plant Material. The leaf of Aerva lanata was obtained from the Igando area of Lagos in Nigeria in May 2013. It was identified and authenticated by Dr. A. B. Kadiri of the Department of Botany, University of Lagos, Nigeria, and a voucher specimen with reference number LUH 5600 was deposited in the university herbarium. The plant material was dried to constant weight in the laboratory at room temperature $\left(22-25^{\circ} \mathrm{C}\right)$ and later grounded to powder using a laboratory blender.

2.3. Extract Preparation. Dried powdered material (30 g) was divided into three equal portions each weighing $10 \mathrm{~g}$. Each portion was extracted in either $200 \mathrm{~mL}$ distilled water, ethanol, or hydroethanol $(50: 50)$ for $24 \mathrm{~h}$. The extracts were centrifuged (Hermle Laboratory Centrifuge, Lasec, South Africa) and later filtered using Whatman No. 1 filter paper. The ethanol extract was concentrated to dryness using a rotary evaporator (Cole-Parmer, South Africa) under vacuum while the aqueous extract was freeze-dried in a lyophilizer (VirTis BenchTop, SP Scientific Series, USA). The hydroethanol extract was initially concentrated using a rotary evaporator and later freeze-dried in the lyophilizer. Extracts were dissolved in distilled water to prepare different concentrations $(0.32,0.63,1.25,2.5$, and $5.0 \mathrm{mg} / \mathrm{mL})$ of the extracts.

\subsection{Antidiabetic Potentials}

2.4.1. $\alpha$-Amylase Inhibitory Assay. A total of $250 \mu \mathrm{L}$ of each extract $(0.32-5.0 \mathrm{mg} / \mathrm{mL})$ was placed in a test tube, and $250 \mu \mathrm{L}$ of $0.02 \mathrm{M}$ sodium phosphate buffer ( $\mathrm{pH}$ 6.9) containing $\alpha$-amylase solution was added. This solution was preincubated at $25^{\circ} \mathrm{C}$ for $10 \mathrm{~min}$, after which $250 \mu \mathrm{L}$ of $1 \%$ starch solution in $0.02 \mathrm{M}$ sodium phosphate buffer ( $\mathrm{pH} 6.9$ ) was added at timed intervals and then incubated at $25^{\circ} \mathrm{C}$ for $10 \mathrm{~min}$. The reaction was terminated by adding $500 \mu \mathrm{L}$ of the dinitrosalicylic acid (DNS) reagent. The tubes were then incubated in boiling water for $5 \mathrm{~min}$ and cooled to room temperature. The reaction mixture was diluted with $5 \mathrm{~mL}$ distilled water, and the absorbance was measured at $540 \mathrm{~nm}$ using a spectrophotometer (Biowave II, Biochrom, UK) [10]. The control was prepared using the same procedure by replacing the extract with distilled water, while the activity of the standard was tested by replacing the extract with acarbose. The $\alpha$-amylase inhibitory activity was calculated as percentage inhibition; thus,

$$
\% \text { inhibition }=\left[\frac{\mathrm{Abs}_{\text {control }}-\mathrm{Abs}_{\text {extract }}}{\mathrm{Abs} \mathrm{control}_{\text {col }}}\right] \times 100 .
$$

2.4.2. Mode of $\alpha$-Amylase Inhibition. We followed the method of Kazeem and Ashafa [11] to determine the mode of inhibition of $\alpha$-amylase by the plant extracts using the most potent extract. Briefly, $250 \mu \mathrm{L}$ of the $(1.25 \mathrm{mg} / \mathrm{mL})$ hydroethanol extract was preincubated with $250 \mu \mathrm{L}$ of $\alpha$ amylase solution for $10 \mathrm{~min}$ at $25^{\circ} \mathrm{C}$ in one set of tubes. In another set of tubes, $\alpha$-amylase was preincubated with $250 \mu \mathrm{L}$ of phosphate buffer (pH 6.9). $250 \mu \mathrm{L}$ of starch solution at increasing concentrations $(25-400 \mu \mathrm{g} / \mathrm{mL})$ was added to both sets of reaction mixtures to start the reaction. The mixtures were then incubated for $10 \mathrm{~min}$ at $25^{\circ} \mathrm{C}$ and boiled for $5 \mathrm{~min}$ after the addition of $500 \mu \mathrm{L}$ of DNS to stop the reaction. The amount of reducing sugars released was determined spectrophotometrically using a maltose standard curve and converted to reaction velocities. A double reciprocal (Lineweaver-Burk) plot $(1 / v$ versus $1 /[S])$ where $v$ is the reaction velocity and $[S]$ is the substrate concentration was plotted to determine the mode of inhibition.

2.4.3. $\alpha$-Glucosidase Inhibitory Assay. Briefly, rat intestinal acetone powder $(100 \mathrm{mg})$ was homogenized in $3 \mathrm{~mL}$ of $0.9 \% \mathrm{NaCl}$ solution. After centrifugation $(12000 \times \mathrm{g}$ for $30 \mathrm{~min})$, the crude enzyme $(100 \mu \mathrm{L})$ was incubated with $5 \mathrm{mM}$ p-nitrophenyl glucopyranoside (pNPG) and $25 \mathrm{mM}$ maltose or $50 \mathrm{mM}$ sucrose in $0.1 \mathrm{M}$ phosphate buffer ( $\mathrm{pH}$ 6.9). This was followed by the addition of plant extracts $(50 \mu \mathrm{L})$ of different concentrations $(0.32-5.0 \mathrm{mg} / \mathrm{mL})$ to the mixture before incubation at $37^{\circ} \mathrm{C}$ for $30 \mathrm{~min}$. The reaction was stopped by adding $50 \mu \mathrm{L}$ of $0.1 \mathrm{M} \mathrm{Na}_{2} \mathrm{CO}_{3}$. The enzyme activities were determined by measuring the absorbance at $405 \mathrm{~nm}$ ( $\alpha$-glucosidase) or $540 \mathrm{~nm}$ (maltase and sucrase) [12]. The control was prepared using the same procedure by replacing the extract with distilled water while the activity of the standard was tested by replacing the extract with acarbose. The percentage inhibition was calculated as follows:

$$
\% \text { inhibition }=\left[\frac{\mathrm{Abs}_{\text {control }}-\mathrm{Abs}_{\text {extract }}}{\mathrm{Abs} \mathrm{control}_{\text {col }}}\right] \times 100 .
$$

2.4.4. Mode of $\alpha$-Glucosidase Inhibition. We followed the method of Kazeem and Ashafa [11] to determine the mode of inhibition of $\alpha$-glucosidase by the extracts using the extract 
with the lowest $\mathrm{IC}_{50}$. Briefly, $50 \mu \mathrm{L}$ of the $(1.25 \mathrm{mg} / \mathrm{mL})$ aqueous extract was preincubated with $100 \mu \mathrm{L}$ of $\alpha$-glucosidase solution for $10 \mathrm{~min}$ at $25^{\circ} \mathrm{C}$ in one set of tubes. In another set of tubes, $\alpha$-glucosidase was preincubated with $50 \mu \mathrm{L}$ of phosphate buffer ( $\mathrm{pH} 6.9$ ). $50 \mu \mathrm{L}$ of PNPG, maltose, or sucrose at increasing concentrations $(25-400 \mu \mathrm{g} / \mathrm{mL})$ was added to both sets of reaction mixtures to start the reaction. The mixtures were then incubated for $10 \mathrm{~min}$ at $25^{\circ} \mathrm{C}$, and $500 \mu \mathrm{L}$ of $\mathrm{Na}_{2} \mathrm{CO}_{3}$ was added to stop the reaction. The amount of reducing sugars released was determined spectrophotometrically using a para-nitrophenol standard curve and converted to reaction velocities. A double reciprocal (Lineweaver-Burk) plot ( $1 / v$ versus $1 /[S])$ where $v$ is the reaction velocity and $[S]$ is the substrate concentration was plotted to determine the mode of inhibition.

2.4.5. Determination of $I C_{50}$ Values of Antidiabetic Assays. The concentration of extracts or standard required to inhibit $50 \%$ of the enzyme concentration is known as $\mathrm{IC}_{50} . \mathrm{IC}_{50}$ values were determined from the percentage inhibitory capacities of the extracts using Microsoft Excel software.

\subsection{Antioxidant Activities}

2.5.1. DPPH Free Radical-Scavenging Ability. Different concentrations $(0.32-5.0 \mathrm{mg} / \mathrm{mL})$ of the extracts $(150 \mu \mathrm{L})$ were mixed with $150 \mu \mathrm{L}$ of $0.4 \mathrm{mmol} / \mathrm{L}$ methanolic solution containing DPPH radicals. The mixture was left in the dark for $30 \mathrm{~min}$, and the absorbance was measured at $516 \mathrm{~nm}$ using a microplate reader (Model 680, Bio-Rad). The DPPH free radical-scavenging ability of each extract was subsequently calculated with respect to the reference (which contains all the reagents without the test sample) [13]. The DPPH free radical-scavenging ability of the standard antioxidant was also tested by replacing the extract with quercetin.

2.5.2. Superoxide Anion Radical-Scavenging Ability. Superoxide radicals were generated in $50 \mu \mathrm{L}$ of Tris- $\mathrm{HCl}$ buffer (16 mM, pH 8.0) containing $50 \mu \mathrm{L}$ of NBT ( $50 \mathrm{mM})$ solution, $50 \mu \mathrm{L} \mathrm{NADH}(78 \mathrm{mM})$ solution, and different concentrations $(0.32-5.0 \mathrm{mg} / \mathrm{mL})$ of the extracts $(100 \mu \mathrm{L})$. The reaction started by adding $1 \mathrm{~mL}$ of phenazine methosulphate (PMS) solution $(10 \mathrm{mM})$ to the mixture. The reaction mixture was incubated at $25^{\circ} \mathrm{C}$ for $5 \mathrm{~min}$, and the absorbance was measured at $560 \mathrm{~nm}$ in a microplate reader (Model 680, BioRad, USA) [14]. The superoxide anion radical-scavenging ability of the standard antioxidant was also tested by replacing the extract with quercetin.

2.5.3. Determination of $E_{50}$ Values of Antioxidant Assays. The concentration of extracts or standard required to scavenge $50 \%$ of free radicals or chelate metal ions is known as $\mathrm{EC}_{50} . \mathrm{EC}_{50}$ values were determined from the free radicalscavenging or iron-chelating abilities of the extracts using Microsoft Excel software.

2.6. Statistical Analysis. Statistical analysis was performed using the GraphPad Prism 5 statistical package (GraphPad Software Inc., La Jolla, CA, USA). The data were analyzed by one-way analysis of variance (ANOVA) followed by the
Bonferroni test. All the results were expressed as mean \pm SEM for triplicate determinations.

\section{Results}

Figure 1 shows the inhibitory effects of different extracts of Aerva lanata on the activities of $\alpha$-amylase and $\alpha$-glucosidase. At lower concentrations $(0.32-0.63 \mathrm{mg} / \mathrm{mL})$ and $2.5 \mathrm{mg} / \mathrm{mL}$, the ethanol extract displayed significantly higher inhibition of $\alpha$-amylase compared to the other extracts (Figure 1(A)). However, at concentrations 1.25 and $5.0 \mathrm{mg} /$ $\mathrm{mL}$, the hydroethanol and aqueous extracts, respectively, displayed significantly lower inhibition of the enzyme. At the lowest $(0.32 \mathrm{mg} / \mathrm{mL})$ and highest concentrations $(5.0 \mathrm{mg} / \mathrm{mL})$, the percentage inhibition of $\alpha$-glucosidase by the aqueous extract is significantly lower and higher, respectively, compared to the other extracts (Figure 1(B)). In between these concentrations, the hydroethanol extract displayed significantly higher inhibition of the enzyme compared to other extracts.

Table 1 shows the $\mathrm{IC}_{50}$ for the inhibition of the activities of $\alpha$-amylase and $\alpha$-glucosidase by the different extracts of Aerva lanata. As for $\alpha$-amylase, the ethanol extract displayed the lowest $\mathrm{IC}_{50}$ compared to the other extracts but was similar to the standard, acarbose. On the other hand, the hydroethanol extract displayed the lowest $\mathrm{IC}_{50}$ for the inhibition of $\alpha$-glucosidase compared to all the extracts and the standard.

The mode of inhibition of the enzymes by the hydroethanol extract of Aerva lanata is shown in Figure 2. Figures 2(a) and 2(b) depict that the hydroethanol extract of Aerva lanata inhibited both $\alpha$-amylase and $\alpha$-glucosidase in an uncompetitive manner.

Figure 3 shows the result of the DPPH and ABTS radicalscavenging abilities of different extracts of the Aerva lanata leaf. Though there are variations, there is no significant difference in the DPPH radical-scavenging abilities among all the extracts tested except for the concentration of $0.63 \mathrm{mg} /$ $\mathrm{mL}$ where the aqueous extract is significantly different from the hydroethanol extract (Figure 3(A)). A similar trend is also reflected in the ABTS radical-scavenging abilities where the scavenging abilities of the extracts are similar except at the concentration of $1.25 \mathrm{mg} / \mathrm{mL}$ in which the activities of the aqueous extract of the plant are significantly higher than those of the ethanol extract.

Table 2 presents the $\mathrm{EC}_{50}$ for the free radical-scavenging abilities of the various extracts of Aerva lanata. Among all the extracts, the hydroethanol extract exhibited the lowest $\mathrm{EC}_{50}$ for the DPPH radical-scavenging ability but was similar to the ethanol extract and significantly higher than the standard, gallic acid. Conversely, the aqueous extract of Aerva lanata displayed the lowest $\mathrm{EC}_{50}$ for the ABTS radical-scavenging abilities compared to the extracts and the standard. However, the $\mathrm{EC}_{50}$ for free radical-scavenging abilities exhibited by both ethanol and hydroethanol extracts are similar.

The phenolic and flavonoid composition of various extracts of Aerva lanata is shown in Table 3. The hydroethanol extract possessed the highest quantity of phenolics 


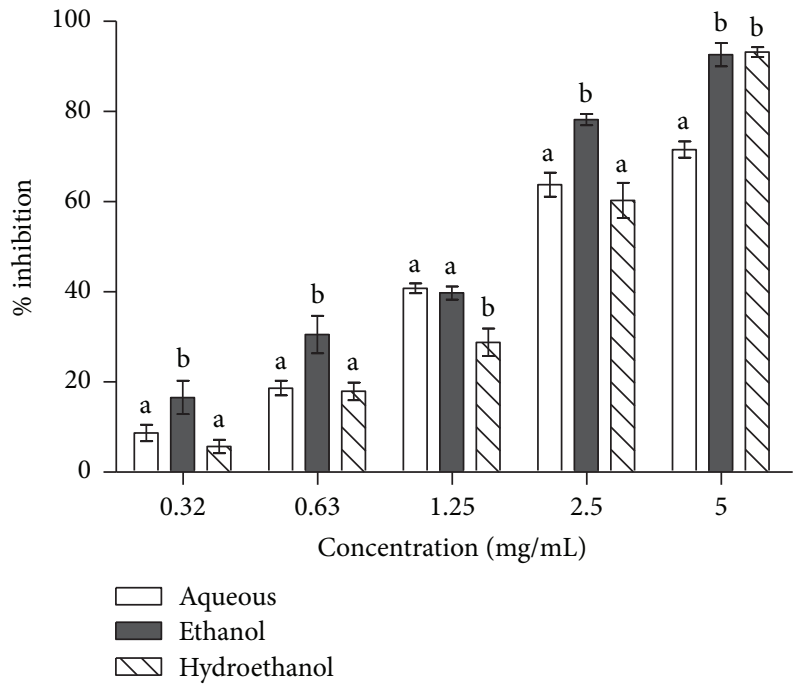

(a)

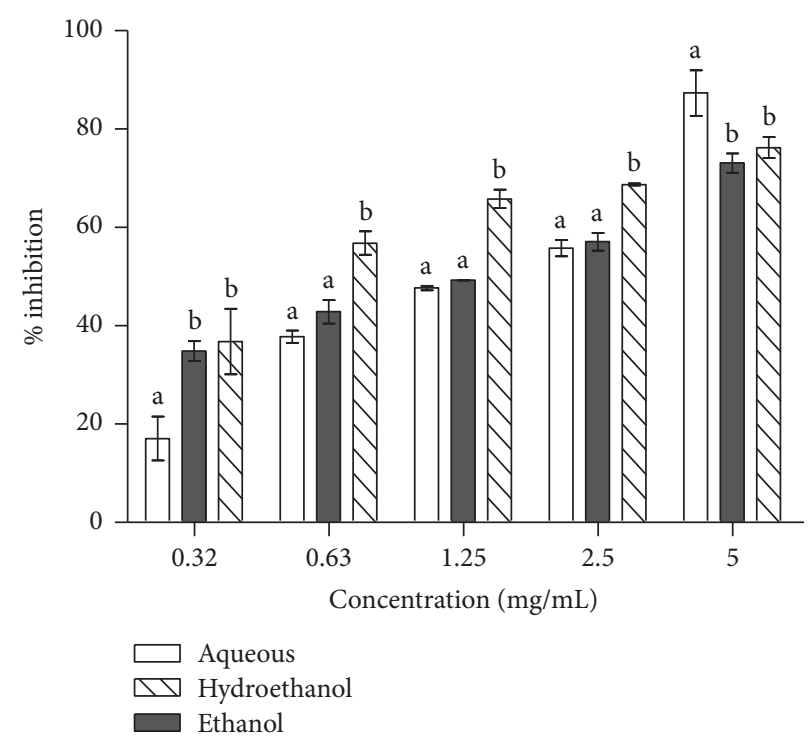

(b)

Figure 1: Inhibitory effects of leaf extracts of Aerva lanata on the activities of (a) $\alpha$-amylase and (b) $\alpha$-glucosidase. Bars carrying different letters at the same concentration are significantly different $(p<0.05)$.

TABLE 1: $\mathrm{IC}_{50}$ values for in vitro $\alpha$-amylase and $\alpha$-glucosidase inhibition by various extracts of Aerva lanata and acarbose.

\begin{tabular}{lcc}
\hline \multirow{2}{*}{ Extracts } & \multicolumn{2}{c}{$\mathrm{IC}_{50}(\mathrm{mg} / \mathrm{mL})$} \\
& $\alpha$-Amylase & $\alpha$-Glucosidase \\
\hline Aqueous & $2.66 \pm 0.15^{\mathrm{a}}$ & $2.01 \pm 0.12^{\mathrm{a}}$ \\
Ethanol & $1.85 \pm 0.03^{\mathrm{b}}$ & $1.75 \pm 0.05^{\mathrm{b}}$ \\
Hydroethanol & $2.42 \pm 0.05^{\mathrm{a}}$ & $0.23 \pm 0.02^{\mathrm{c}}$ \\
Acarbose & $2.10 \pm 0.07^{\mathrm{b}}$ & $1.63 \pm 0.10^{\mathrm{b}}$ \\
\hline
\end{tabular}

followed by the aqueous extract. However, the ethanol extract is the richest in flavonoids compared to the other extracts.

\section{Discussion}

We investigated the antidiabetic and free radical-scavenging properties of different extracts of Aerva lanata using in vitro models. Its antidiabetic properties was assessed by testing for its inhibitory effect on $\alpha$-amylase and $\alpha$-glucosidase, while the antioxidant activities were investigated by evaluating its ability to scavenge DPPH and superoxide radicals.

Inhibition of enzymes involved in the hydrolysis of carbohydrates such as $\alpha$-amylase and $\alpha$-glucosidase is one of the therapeutic approaches for diabetes-related hyperglycemia [3]. Pancreatic $\alpha$-amylase is involved in the conversion of starch into disaccharides and oligosaccharides while intestinal $\alpha$-glucosidase catalyzes the breakdown of disaccharides into glucose [15]. Inhibition of these enzymes would slow down the degradation of starch in the gastrointestinal tract, thereby ameliorating hyperglycemia.

The ethanol extract of Aerva lanata displayed the strongest inhibition of $\alpha$-amylase which culminated in the lowest $\mathrm{IC}_{50}$ when compared to other extracts and acarbose. This is undesirable of a good hypoglycemic agent as excessive inhibition of the enzyme is responsible for drawbacks associated with acarbose such as abdominal distention and hypoglycemia [16]. The hydroethanol extract on the other hand exhibited the strongest inhibition of $\alpha$-glucosidase and possessed the lowest $\mathrm{IC}_{50}$ for the inhibition of the enzyme. Taken together, the hydroethanol extract of Aerva lanata seems to be the most potent inhibitor of both enzymes due to its mild inhibition of $\alpha$-amylase and strong inhibition of $\alpha$-glucosidase. This is in conformity with previous reports that a desirable antidiabetic agent from a plant should be a mild inhibitor of $\alpha$-amylase and strong inhibitor of $\alpha$-glucosidase $[10,14]$.

In order to determine the modes of inhibition of the enzymes by Aerva lanata, the most potent extract (hydroethanol) of the plant was chosen for the study. The Lineweaver-Burk plot revealed that the hydroethanol extract of Aerva lanata inhibited both $\alpha$-amylase and $\alpha$-glucosidase in an uncompetitive manner. This implies that the active component in the extract only recognizes and binds to the enzyme-substrate (ES) complex, without binding to the free enzyme [17]. This type of inhibition is characterized by a reduction in both substrates $\mathrm{K}_{\mathrm{m}}$ and $\mathrm{V}_{\text {max }}$, and the inhibitor binds to the enzyme target only when the target is active and the substrate is present [18]. This may be useful in the design of $\alpha$-amylase and $\alpha$-glucosidase inhibitors for the treatment of diabetes mellitus.

Oxidative stress has been implicated in the pathogenesis of several diseases including diabetes mellitus. Previous studies also showed that hyperglycemia induces the generation of free radicals, which aggravates the development of diabetes and its associated complications $[19,20]$. This is why the antioxidant potential of the Aerva lanata extracts was assessed to ascertain the relationship between antidiabetic and antioxidant potentials of the plant. The hydroethanol extract of the plant displayed the lowest $\mathrm{EC}_{50}$ for the 


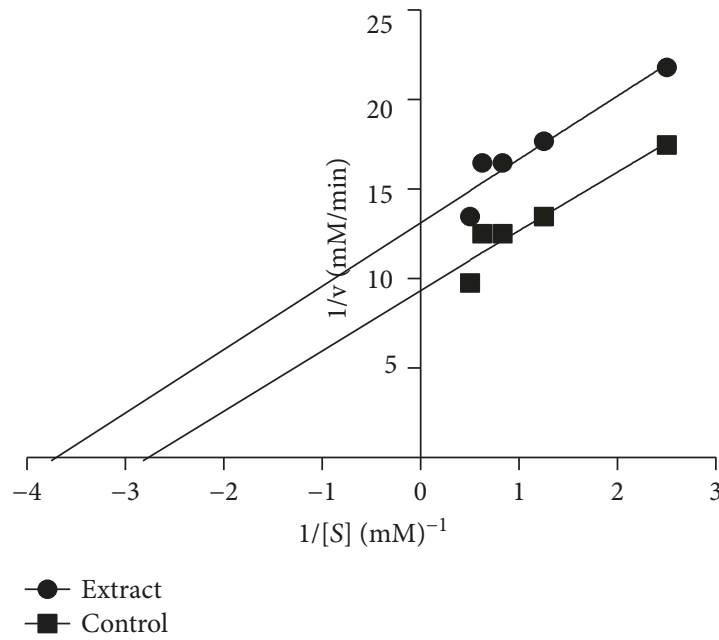

(a)

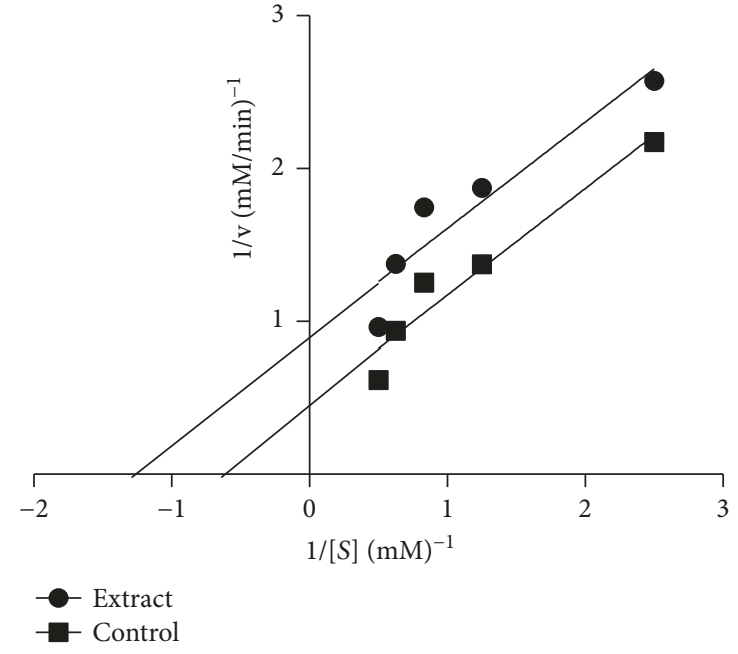

(b)

Figure 2: Mode of inhibition of (a) $\alpha$-amylase and (b) $\alpha$-glucosidase by the hydroethanol extract of the Aerva lanata leaf.

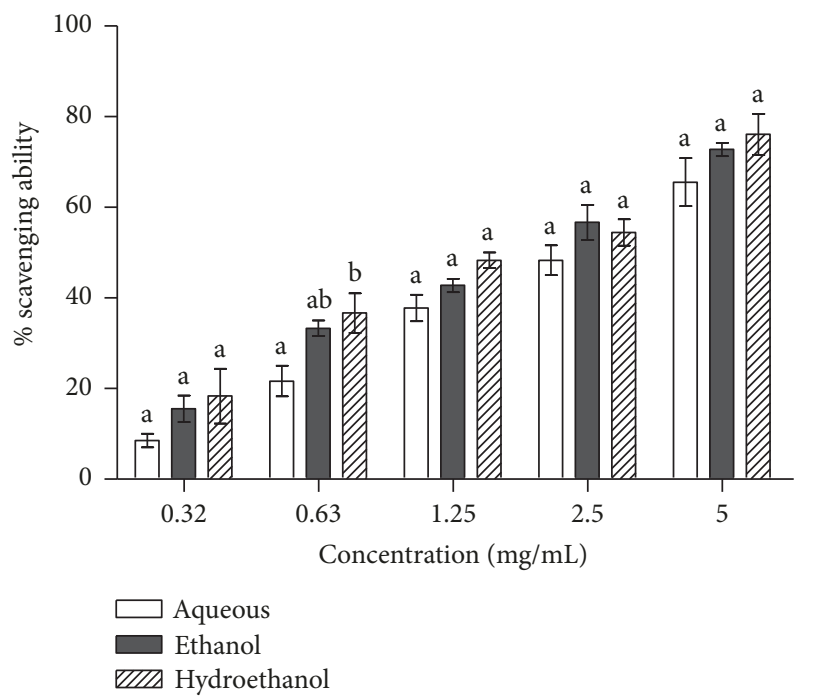

(a)

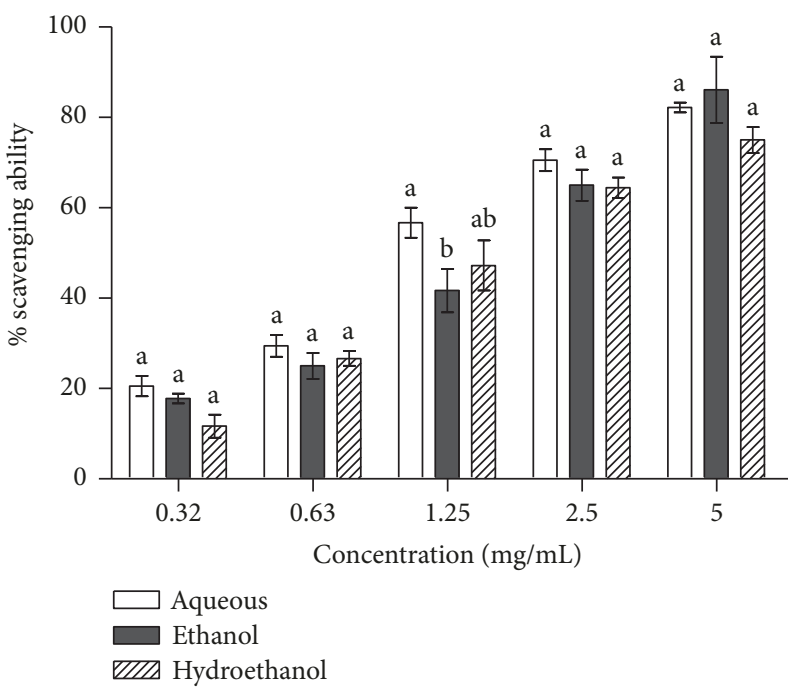

(b)

FIgURE 3: (a) DPPH and (b) ABTS radical-scavenging abilities of leaf extracts of Aerva lanata. Bars carrying different letters at the same concentration are significantly different $(p<0.05)$.

TABLE 2: $\mathrm{EC}_{50}$ values for the free radical-scavenging activities of different extracts of Aerva lanata leaves.

\begin{tabular}{lcc}
\hline \multirow{2}{*}{ Extract } & \multicolumn{2}{c}{$\mathrm{EC}_{50}(\mathrm{mg} / \mathrm{mL})$} \\
& $\mathrm{DPPH}$ & ABTS \\
\hline Aqueous & $3.18 \pm 0.04^{\mathrm{a}}$ & $1.79 \pm 0.06^{\mathrm{a}}$ \\
Ethanol & $2.48 \pm 0.01^{\mathrm{b}}$ & $2.14 \pm 0.10^{\mathrm{b}}$ \\
Hydroethanol & $2.25 \pm 0.04^{\mathrm{b}}$ & $2.35 \pm 0.02^{\mathrm{b}}$ \\
Gallic acid & $1.25 \pm 0.02^{\mathrm{c}}$ & $2.03 \pm 0.02^{\mathrm{c}}$ \\
\hline
\end{tabular}

scavenging of DPPH radicals, which implies that it possessed the best DPPH radical-scavenging abilities. On the contrary, the aqueous extract of the plant exhibited the lowest $\mathrm{IC}_{50}$ for scavenging of superoxide radical (ABTS). The superoxide radical is implicated in several diseases because it plays an
TABle 3: Total phenolic and flavonoid composition of Aerva lanata leaves.

\begin{tabular}{lcc}
\hline Extract & Phenolics $(\mathrm{mg} / \mathrm{g})$ & Flavonoids $(\mathrm{mg} / \mathrm{g})$ \\
\hline Aqueous & $55.91 \pm 2.75^{\mathrm{a}}$ & $7.89 \pm 0.11^{\mathrm{a}}$ \\
Ethanol & $30.72 \pm 3.01^{\mathrm{b}}$ & $17.67 \pm 0.25^{\mathrm{b}}$ \\
Hydroethanol & $78.15 \pm 2.50^{\mathrm{c}}$ & $14.30 \pm 0.40^{\mathrm{b}}$ \\
\hline
\end{tabular}

important role in the formation of other reactive oxygen species such as hydroxyl radical and singlet oxygen, which causes oxidative damage to biomolecules [21,22].

In consonance with the outcome of the in vitro hypoglycemic and antioxidant abilities of Aerva lanata extracts, compositional analysis revealed that the hydroethanol extract is the richest in terms of phenolics. Phenolic compounds are 
one of the most numerous and widely distributed secondary metabolites in plants [23]. They possess a wide range of pharmacological activities including antimicrobial, antidiabetic, anticancer, anti-inflammatory, and antithrombotic activities [24]. All these functions have been attributed to their chemical composition and antioxidant properties. It can therefore be suggested that the antidiabetic activities of the Aerva lanata extracts may be due to the phenolic composition of the plant and its antioxidant activities.

In conclusion, the aqueous, ethanol, and hydroethanol extracts of the Aerva lanata leaf inhibited the activities of diabetes-related enzymes and possessed free radicalscavenging abilities. Out of the three extracts, the hydroethanol extract displayed the most effective antidiabetic as well as antioxidant potential. This may be due to its high phenolic content.

\section{Data Availability}

The data used to support the findings of this study are included within the article.

\section{Conflicts of Interest}

The authors declare that there is no conflict of interest regarding the publication of this paper.

\section{Acknowledgments}

The authors acknowledge the support of the University of Ilorin, Ilorin, Nigeria, and Lagos State University, Lagos, Nigeria, in the conduct of the experiments and preparation of the manuscript.

\section{References}

[1] K. Ogurtsova, J. D. da Rocha Fernandes, Y. Huang et al., "IDF diabetes atlas: global estimates for the prevalence of diabetes for 2015 and 2040," Diabetes Research and Clinical Practice, vol. 128, pp. 40-50, 2017.

[2] M. I. Kazeem, H. A. Bankole, A. A. Fatai, A. F. Adenowo, and T. C. Davies, "Antidiabetic functional foods with antiglycation properties," in Bioactive Molecules in Food, J.-M. Mérillon and K. G. Ramawat, Eds., pp. 1-29, Springer, Cham, Switzerland, 2018.

[3] A. Cheng and I. Fantus, "Oral antihyperglycemic therapy for type 2 diabetes mellitus," Canadian Medical Association Journal, vol. 172, no. 2, pp. 213-226, 2005.

[4] G. Oboh, A. A. Olabiyi, A. J. Akinyemi, and A. O. Ademiluyi, "Inhibition of key enzymes linked to type 2 diabetes and sodium nitroprusside-induced lipid peroxidation in rat pancreas by water-extractable phytochemicals from unripe pawpaw fruit (Carica papaya)," Journal of Basic and Clinical Physiology and Pharmacology, vol. 25, no. 1, pp. 21-34, 2014.

[5] G. Kumar, L. Karthik, and K. V. B. Rao, "Phytochemical composition and in vitro antioxidant activity of aqueous extract of Aerva lanata (L.) Juss. ex Schult. Stem (Amaranthaceae)," Asian Pacific Journal of Tropical Medicine, vol. 6, no. 3, pp. 180-187, 2013.

[6] T. Vetrichelvan and M. Jegadeesan, "Anti-diabetic activity of alcoholic extract of Aerva lanata (L.) Juss. ex Schultes in rats,"
Journal of Ethnopharmacology, vol. 80, no. 2-3, pp. 103-107, 2002.

[7] R. Rajesh, K. Chitra, and P. M. Paarakh, "Aerva lanata (Linn.) Juss. ex Schult.- an overview," Indian Journal of Natural Products and Resources, vol. 2, no. 1, pp. 5-9, 2011.

[8] Y. Mariswamy, W. E. Gnaraj, and J. M. Antonisamy, "Chromatographic fingerprint analysis on flavonoids constituents of the medicinally important plant Aerva lanata L. by HPTLC technique," Asian Pacific Journal of Tropical Biomedicine, vol. 1, no. 1, pp. S8-S12, 2011.

[9] M. Goyal, B. P. Nagori, A. Pareek, and D. Sasmal, "Aerva lanata: a review on phytochemistry and pharmacological aspects," Pharmacognosy Reviews, vol. 5, no. 10, pp. 195-198, 2011.

[10] P. P. McCue and K. Shetty, "Inhibitory effects of rosmarinic acid extracts on porcine pancreatic amylase in vitro," Asia Pacific Journal of Clinical Nutrition, vol. 13, no. 1, 2004.

[11] M. I. Kazeem and A. O. T. Ashafa, "Antioxidant and inhibitory properties of Dombeya burgessiae leaf extracts on enzymes linked to diabetes mellitus," Transactions of the Royal Society of South Africa, vol. 71, no. 2, pp. 167-174, 2016.

[12] S. Adisakwattana, P. Charoenlertkul, and S. Yibchok-anun, “ $\alpha$ Glucosidase inhibitory activity of cyanidin-3-galactoside and synergistic effect with acarbose," Journal of Enzyme Inhibition and Medicinal Chemistry, vol. 24, no. 1, pp. 65-69, 2009.

[13] M. R. Saha, S. M. R. Hasan, R. Akter et al., "In vitro free radical scavenging activity of methanol extract of the leaves of Mimusops elengi Linn," Bangladesh Journal of Veterinary Medicine, vol. 6, no. 2, pp. 197-202, 2008.

[14] N. Mbhele, F. O. Balogun, M. I. Kazeem, and T. Ashafa, "In vitro studies on the antimicrobial, antioxidant and antidiabetic potential of Cephalaria gigantea," Bangladesh Journal of Pharmacology, vol. 10, no. 1, pp. 214-221, 2015.

[15] S. A. Adefegha and G. Oboh, "Inhibition of key enzymes linked to type 2 diabetes and sodium nitroprusside-induced lipid peroxidation in rat pancreas by water extractable phytochemicals from some tropical spices," Pharmaceutical Biology, vol. 50, no. 7, pp. 857-865, 2012.

[16] E. Apostolidis, Y.-I. Kwon, and K. Shetty, "Inhibitory potential of herb, fruit, and fungal-enriched cheese against key enzymes linked to type 2 diabetes and hypertension," Innovative Food Science \& Emerging Technologies, vol. 8, no. 1, pp. 46-54, 2007.

[17] D. L. Nelson and M. M. Cox, Lehninger Principles of Biochemistry, WH Freeman and Company, New York, NY, USA, 4th edition, 2004.

[18] I. G. Dougall and J. Unitt, "Evaluation of the biological activity of compounds: techniques and mechanism of action studies," in The Practice of Medicinal Chemistry, C. G. Wermuth, D. Aldous, P. Raboisson, and D. Rognan, Eds., pp. 15-43, Elsevier, 2015.

[19] A. J. Afolayan and T. O. Sunmonu, "Protective role of Artemisia afra aqueous extract on tissue antioxidant defense systems in streptozotocin-induced diabetic rats," African Journal of Traditional, Complementary and Alternative Medicines, vol. 10, no. 1, pp. 15-20, 2013.

[20] F. Giacco and M. Brownlee, "Oxidative stress and diabetic complications," Circulation Research, vol. 107, no. 9, pp. 1058-1070, 2010.

[21] İ. Gülçin, Z. Huyut, M. Elmastaş, and H. Y. Aboul-Enein, "Radical scavenging and antioxidant activity of tannic acid," Arabian Journal of Chemistry, vol. 3, no. 1, pp. 43-53, 2010. 
[22] H. S. Tohma and I. Gulçin, "Antioxidant and radical scavenging activity of aerial parts and roots of Turkish liquorice (Glycyrrhiza glabra L.)," International Journal of Food Properties, vol. 13, no. 4, pp. 657-671, 2010.

[23] M. A. Soobrattee, V. S. Neergheen, A. Luximon-Ramma, O. I. Aruoma, and T. Bahorun, "Phenolics as potential antioxidant therapeutic agents: mechanism and actions," Mutation Research, vol. 579, no. 1-2, pp. 200-213, 2005.

[24] F. Shahidi and P. Ambigaipalan, "Phenolics and polyphenolics in foods, beverages and spices: antioxidant activity and health effects-a review," Journal of Functional Foods, vol. 18, pp. 820-897, 2015. 


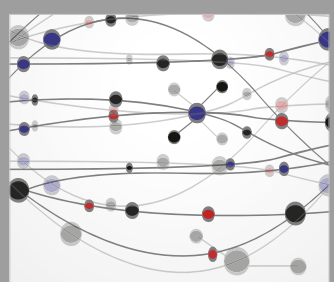

The Scientific World Journal
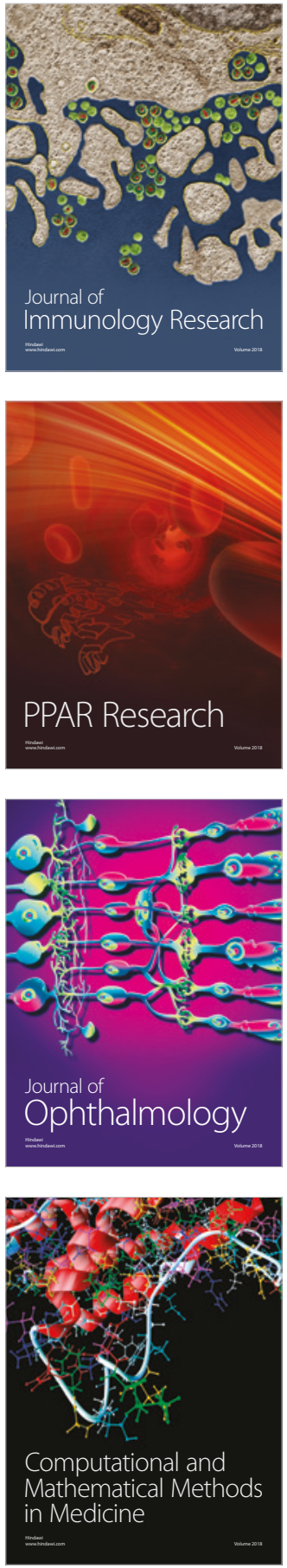

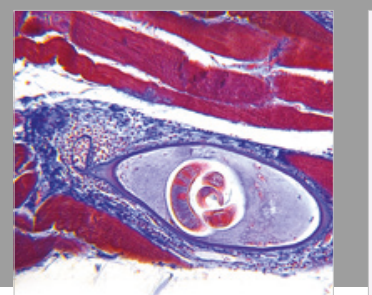

Gastroenterology Research and Practice

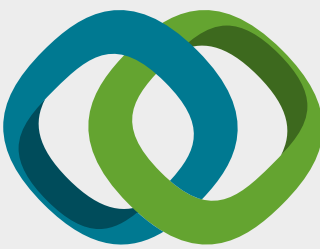

\section{Hindawi}

Submit your manuscripts at

www.hindawi.com
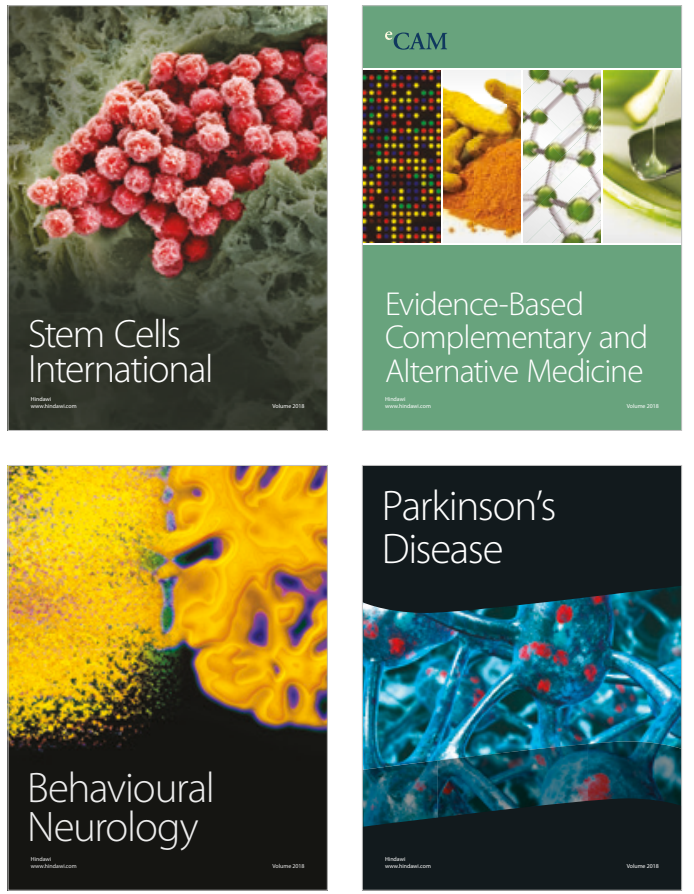

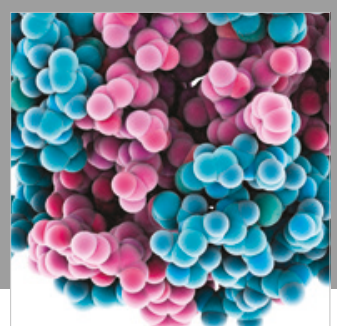

ournal of

Diabetes Research

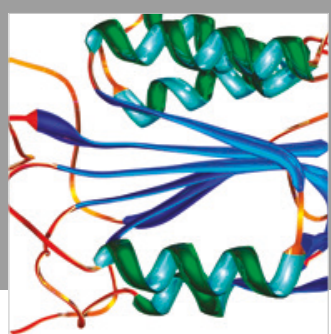

Disease Markers
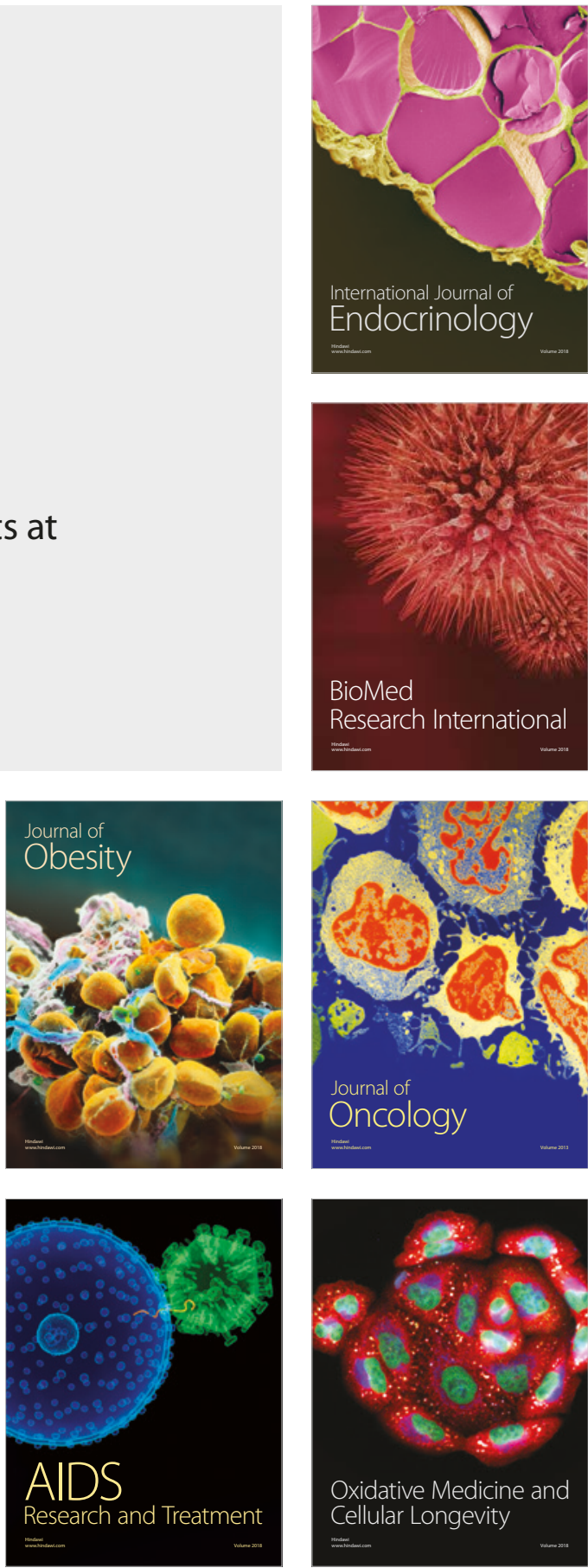